\title{
Insurance Premium
}

\section{Helmut Heiss}

Published online: 3 September 2008

(C) ERA 2008

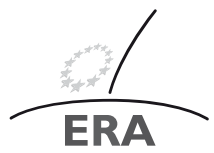

EUROPÄISCHE RECHTSAKADEMIE ACADEMY OF EUROPEAN LAW ACADEMIE DE DROIT EUROPEEN ACADEMIE DE DROIT EUROPEEN TRIER - TREVES - TREYIRI

\section{Article 5:101. First or Single Premium}

When the insurer makes payment of the first or single premium a condition of formation of the contract or of the beginning of cover, that condition shall be without effect unless

(a) the condition is communicated to the applicant in writing using clear language and warning the applicant that he lacks cover until the premium is paid, and (b) a period of two weeks has expired after receipt of an invoice which complies with requirement (a) without payment having been made.

\section{Comments}

\section{Scope of regulation}

The scope of regulation of Article 5:101 is limited in several ways. First of all, it only deals with certain aspects of non-payment of premium leaving questions of performance such as the place, time and mode of payment of the premium to the general rules as contained in the PECL (see Articles 7:101, 7:102, 7:107 and 7:108). Secondly, Article 5:101 only deals with first premiums or single premiums (as to the meaning of these terms, see Comment 3 below), whereas subsequent premiums are dealt with

Prof. Dr. jur. Helmut Heiss $(\bowtie)$

University Zürich, Chair for Private Law and Comparative Law

Treichlerstrasse 10, 8032 Zürich, Switzerland

e-mail: helmut.heiss@rwi.unizh.ch

This paper is the written version of the presentation given by the author at the conference European Insurance Contract Law and the Common Frame of Reference (CFR), organised by ERA and the Joint Network on European Private Law in Trier on 21-22 January 2008. 
in Article 5:102. Thirdly, Article 5:101 only deals with the impact of non-payment of a first or single premium on the formation of the contract and the commencement of cover under the policy, while the right of the insurer to terminate the contract following non-payment of premium is dealt with in Article 5:103.

\section{Regulatory approach}

Article 5:101 restricts itself to limiting the effect of any condition imposed by the insurer by which the formation of the contract or the commencement of the cover under the policy depends on prior payment of the first or single premium. Article 5:101 itself neither requires pre-payment of the premium nor does it revoke cover in case of non-payment. Thus, in the absence of a condition imposed by the insurer, non-payment of the first or single premium will have no impact on the conclusion of the contract and the provision of cover by the insurer. In such cases the insurer will be restricted to enforcing its claim for premium in accordance with Article 9:101(1) PECL and for interest in accordance with Article 9:508 PECL or terminating the contract in accordance with Article 5:103 PEICL.

On the other hand, Article 5:101 does not prohibit a condition requiring payment of premium prior to the formation of the contract or the beginning of the cover. Such a condition is looked upon as a means to deter fraudulent contracting by policyholders. In particular, it makes it impossible for them to enjoy cover, at least for a certain amount of time, under a contract which was concluded knowing that they were not going to pay the premium - whether they were unable or simply unwilling to do so. Of course, policyholders could nevertheless obtain cover without advance payment of premium by means of preliminary cover if the insurer is willing to grant it (see, however, Article 2:403 and especially its para. 2 addressing the problem of preliminary cover obtained fraudulently).

Article 5:101 applies no matter what kind of condition the insurer chooses to impose. In practice, mainly two patterns are followed by insurers. In some countries, the offer of the insurer or the insurer's acceptance of the application for insurance, as the case may be, is conditional on the advanced payment of premium. As a consequence, subject to Article 5:101, a contract of insurance will only be formed and cover will only start to run upon payment of the premium. In other countries, insurers insert specific clauses into their general contract terms which become part of the contract by parties' agreement and make the commencement of the cover, but not the conclusion of the contract, dependent on payment of the first or single premium.

\section{First and single premium}

In view of Article 5:102, the distinction between first premiums and subsequent premiums becomes vital. In principle, the „first premium” is the premium due which falls due immediately after the conclusion of the contract. Since contracts concluded under the PEICL normally last for one year (see Article 2:601), the premium due for the year after the initial conclusion of the contract is a first premium. In contrast, all premiums due after a prolongation of the contract according to Article 2:602 will be subsequent premiums and not governed by Article 5:101, but by Article 5:102. 
The issue described in the paragraph above does not arise when a single premium is due. A single premium is the only premium which will ever be paid by the policyholder under the policy. Therefore, there will be no subsequent premiums within the meaning of Article 5:102 and Article 5:101 will apply to the single premium. In order to avoid any argument to the contrary the wording of Article 5:101 makes its application to single premiums explicit.

Insurers frequently agree that policyholders may pay the premiums by instalments. A premium which is calculated, for example, on a yearly basis may be paid by the policyholder in monthly instalments. In such cases, 'the premium' will only be fully paid about one month before the regular one-year period of the insurance contract comes to an end in accordance with Article 2:601. It would, in these cases, be contrary to the purpose of Articles 5:101 and 5:102, as well as the parties' intention which is expressed in the agreement allowing payment of the first premium by instalments, to apply Article 5:101 to the full amount of the first premium. This is because the conclusion of the contract and/or the commencement of cover would be delayed by about 11 months. It follows that only the first instalment can be considered to be the first premium, while all of the following instalments are subsequent premiums and subject to Article 5:102.

\section{Prerequisites for giving effect to a condition which is subject to article 5:101}

A condition subject to Article 5:101 and imposed by the insurer will only take effect if specific criteria are met. First of all, the policyholder must be warned about the condition and its consequences (Article 5:101(a)). For that purpose, the insurer must give written notice of the condition to the policyholder. Like all documents issued by the insurer, the notice must use plain and intelligible language and must be issued in the language in which the contract was negotiated, as required by Article 1:203 para. 1. The notice must set out the condition imposed by the insurer as well as the consequence of non-payment of the premium, namely the lack of cover.

The warning to be given under Article 5:101(a) may partly overlap with the general duty of the insurer to warn the applicant about the commencement of cover in accordance with Article 2:203, where applicable. In such cases, the insurer must comply with both duties in a manner which is mutually consistent.

The second requirement for a condition subject to Article 5:101 is the receipt of an invoice (Article 5:101(b)). The invoice must not only state the amount of the (first or single) premium but must also comply with the duty to warn which is required of the insurer by Article 5:101(a).

Finally, Article 5:101(b) grants the policyholder a period of two weeks after receipt of an invoice in which to pay the premium. As long as this period has not expired, the policy condition is without effect (for more detail see Comment 5 below).

\section{Consequences of payment or non-payment within the two week period}

If the policyholder pays premium within the two week period, the condition imposed by the insurer 'shall be without effect' and the policyholder, insured or beneficiary, as the case may be, will enjoy cover irrespective of whether an insured event has occurred before or after payment of the first premium. If, in turn, the policyholder does not pay premium within the two week period, cover only commences with actual pay- 
ment and only for the future. During the period until payment is made, including the period of two weeks referred to in Article 5:101(b), the risk will not be covered. However, if the policyholder is prevented from paying, Article 8:108 PECL may apply.

\section{Article 5:102. Subsequent premium}

(1) A clause, providing for the insurer to be relieved of its obligation to cover the risk in the event of non-payment of a subsequent premium, shall be without effect unless

(a) the policyholder receives an invoice stating the precise amount of premium due as well as the date of payment;

(b) after the premium falls due, the insurer sends a reminder to the policyholder of the precise amount of premium due, granting an additional period of payment of at least two weeks, and warning the policyholder of the imminent suspension of cover if payment is not made; and

(c) the additional period in requirement (b) has expired without payment having been made.

(2) The insurer will be relieved of liability after the additional period in para. 1 (b) has expired. Cover will be resumed for the future as soon as the policyholder pays the amount due unless the contract has been terminated in accordance with Article $5: 103$.

\section{Comments}

\section{Scope of regulation}

The scope of regulation in Article 5:102 is subject to the same limitations as Article 5:101; see Comment 1 to Article 5:101 above. However, in contrast to Article 5:101, Article 5:102 deals with non-payment of subsequent premiums; as to the meaning of this term, see Comment 3 below. As a consequence, it only deals with contract clauses, providing for the insurer to be relieved of its obligation to provide cover, but not with conditions unilaterally imposed by the insurer in its initial offer or acceptance; see, in contrast, the third paragraph of Comment 2 to Article 5:101.

\section{Regulatory approach}

Article 5:102 applies the same regulatory approach as Article 5:101. Therefore, it is restricted to limiting the effect of any contract clause by which the provision of cover under the policy depends on prior payment of a subsequent premium. Article 5:102 itself neither requires pre-payment of the premium nor does it revoke cover in case of non-payment. Thus, subject to a clause in the contract providing otherwise, non-payment of a subsequent premium will have no impact on the provision of cover by the insurer. In such cases, the insurer will be restricted to enforcing its claim for premium in accordance with Article 9:101(1) PECL and for interest in accordance with Article 9:508 PECL or, alternatively, terminating the contract in accordance with Article 5:103 PEICL. 


\section{Subsequent premium}

In the context of Article 5:101, the terms 'first premium' and 'single premium' have been defined; see Comment 3. It follows from these definitions that the term 'subsequent premium' must be understood as any premium or instalment of a premium due following payment of a first premium within the meaning of Article 5:101.

\section{Prerequisites for giving effect to a clause which is subject to article 5:102}

The criteria to be met under Article 5:102 in order to relieve the insurer of its obligation to cover the risk go beyond what Article 5:101 requires in the case of nonpayment of a first or single premium. This is justified because at that stage sanctions do not have to deter fraudulent contracting on the part of the policyholder.

First of all, Article 5:102 para. 1(a) requires the insurer to send an invoice to the policyholder in order to make him aware of the premium due. The invoice must at least provide the policyholder with the two most important pieces of information concerning the subsequent premium, namely its precise amount and the date of payment.

If payment is not made in accordance with the invoice, the insurer must send a reminder to the policyholder; see Article 5:102 para. 1(b). The reminder must state the precise amount of the premium due. In addition, it must grant the policyholder a period of grace of at least two weeks. Finally, the reminder must state the consequences of non-payment of the premium within the period of grace, namely the suspension of the cover provided by the contract.

\section{Consequences of payment or non-payment within the period of grace}

If the policyholder pays premium within the period of grace, any insured event will be covered irrespective of whether it occurred before or after payment of premium.

If the policyholder does not pay premium within the period of grace, cover will be suspended with effect from the end of the period of grace; see the first sentence of Article 5:102 para. 2. As a consequence, insured events which occur before the period of grace has ended will be covered.

If the period of grace has ended and cover has been suspended, the policyholder still has the option to resume cover by paying the premium; see the second sentence of Article 5:102 para. 2. Cover will, however, be resumed only for the future. As a consequence, insured events occurring between the end of the period of grace and the payment of premium remain uncovered under the policy.

The option to resume cover by paying premium, as provided for in the second sentence of Article 5:102 para. 2, is lost as soon as the contract is terminated. Termination for non-payment of a subsequent premium is regulated in Article 5:103.

\section{Article 5:103. Termination of the Contract}

(1) On expiry of the period referred to in Article 5:101 (b) or Article 5:102 para. 1 (b), without payment of the premium being made, the insurer shall be entitled to 
terminate the contract by written notice, provided that the invoice required by Article 5:101 (b) or the reminder required by Article 5:102 para. 1 (b), as the case may be, states the right of the insurer to terminate the contract.

(2) The contract shall be deemed to be terminated if, as the case may be, the insurer does not bring an action for payment

(a) of the first premium within two months after expiry of the period mentioned in Article 5:101 (b); or

(b) of a subsequent premium within two months of expiry of the period mentioned in Article 5:102 para. 1 (b).

\section{Comments}

\section{Scope of regulation}

Article 5:103 regulates the insurer's right to terminate the contract in case of nonpayment of premium. It covers non-payment of both a first or single premium and a subsequent premium. However, termination only applies to cases in which a contract has actually been formed. This is not the case where the insurer makes payment of a first or single premium a condition of formation of the contract in accordance with the first of the alternatives stated in Article 5.101 Thus, non-payment of the first or single premium prevents the formation of the contract and, therefore, there is no question of termination.

Article 5:103 states a special, mandatory and comprehensive rule. Thus, it overrides the provisions of the PECL on delay in payment as well as non-payment of money otherwise applicable, namely Articles 8:106(3) and 9:301 to 9:303.

\section{Regulatory approach}

Article 5:103 grants the insurer a right to terminate the contract in case of nonpayment of the premium by the policyholder. The rule primarily serves the interests of the insurer to be able to terminate its contractual relationship with a policyholder, who has proved to be unreliable in paying the premium. Yet, relief from the obligation to provide cover in accordance with conditions of the kind referred to in Articles 5:101 and 5:102 does not fully satisfy the interests of the insurer in termination because it would remain in a relationship which involves some obligations to the policyholder.

On the other hand, Article 5:103 was not needed solely for the purpose of giving the insurer a right of termination, because Articles 8:106(3) and 9:301, 9:304 PECL, which would apply as the lex generalis by virtue of Article 1:105, grant a right to termination anyway. Article 5:103 also lays down mandatory limits on the insurer's right of termination.

\section{Termination in case of non-payment of a first or single premium}

The insurer will only be entitled to terminate the contract if, first of all, the period of two weeks for payment of premium under Article 5:101(b) has ended. Since 
this period will only start to run if the other conditions set out in Article 5:101 are fulfilled, these conditions must also be met. However, in the unlikely case that an insurer does not use the option granted by Article 5:101, it may nevertheless send an invoice to the policyholder and trigger the two-week period for payment of premium.

Furthermore, Article 5:103 para. 1 requires information about the right of termination to be given to the policyholder. This information must be included in the invoice mentioned in Article 5:101(b); see Article 5:103 para. 1.

\section{Termination in case of non-payment of a subsequent premium}

Termination in the case of non-payment of a subsequent premium is regulated in the same way as in the case of non-payment of a first or single premium, with one exception. The exception is that, in the case of non-payment of a subsequent premium, Article 5:103 para. 1 refers to the additional period of payment of at least two weeks and to the reminder mentioned in Article 5:102 para. 1(b) instead of the period of payment and the invoice mentioned in Article 5:101(b).

\section{Notice of termination}

If the insurer wishes to exercise its right to terminate, it must do so by giving the policyholder written notice of termination.

\section{Effects of termination}

The contract will come to an end upon receipt of notice of termination by the policyholder.

Termination under Article 5:103 has no retroactive effects. Therefore, the insurer is entitled to the premium due for the period in which the contract remains in force; with regard to divisibility of the premium, see Article 5:104. This period is, however, restricted by Article 5:103 para. 2; see Comment 7 below.

\section{Automatic termination}

According to Article 5:103 para. 2 the insurer must either terminate the contract or bring an action for payment of premium within a period of two months following the payment periods mentioned in Article 5:103 para. 1. The contract is deemed to be terminated and end automatically if the insurer fails to act in either way within such period. Thus, the insurer cannot let the contract go on indefinitely and collect the premium while cover is withheld in accordance with Article 5:101 or suspended in accordance with Article 5:102.

Article 5:103 para. 2 must not be applied in the unlikely case that the insurer does not use the options granted by Articles 5:101 and 5:102. In such case, if the insurer has a right to terminate under Article 5:103 para. 1 but decides not to use it, no harm will be done to the policyholder. Since cover must be provided by the insurer, it is only reasonable that the policyholder owes any premium due for as long as the insurer does not terminate. 


\section{Article 5:104. Divisibility of Premium}

If an insurance contract is terminated before the contract period has expired, the insurer shall only be entitled to premium in respect of the period prior to termination.

\section{Comments}

\section{The principle}

Article 5:104 establishes the principle of divisibility of premium. Therefore, if a contract is terminated prematurely, the insurer will only be entitled to claim an amount of premium which relates to the period of time before termination took effect. If premium is pre-paid, the insurer must pay back a pro rata share of the premium to the policyholder. For example, a contract concluded for one year but terminated after 10 months will give rise to a claim for repayment of one sixth of the annual premium which was paid in advance.

\section{Abolition of a principle of indivisibility of premium}

Article 5:104 excludes the principle of indivisibility of premium found in some countries because it is not justifiable in this context. Indivisibility is, first of all, no longer required for reasons of practicability. Modern information technology enables the calculation of pro rata premiums at virtually no charge. Secondly, the argument that the insurer needs the premium to fund the relevant risk pool as originally conceived, is unfounded. Following early termination of the contract, the overall exposure of the insurer to risk decreases and the unearned premium is no longer needed to maintain the solvency of the insurer. Thirdly, the risk covered is not indivisible itself. Insurance practice shows that premium for a risk can be calculated on a daily, monthly or yearly basis. Clearly, premiums for cover of a shorter period are lower in absolute terms than premiums for cover of a longer period. Therefore, at least from an economic point of view, risks are divisible in time. There is, of course, the argument that the risk is not even throughout a given period, such as one year. For example in the case of flood insurance, the risk is higher in some seasons than others. However, insurers could tackle this problem by calculating and charging premiums on a monthly basis instead of an annual basis. The principle of divisibility of premium neither prevents nor interferes with such a calculation and charging of premium. Fourthly, the right of the insurer to retain unearned premium cannot be justified as a provision for liquidated damages. In fact, many cases of early termination are not based on a breach of contract on the side of the policyholder. Moreover, the amount of unearned premium depends on the time of termination and, therefore, the amount of liquidated damages will be high if termination comes early but low if it comes relatively late. Finally, indivisibility may be looked upon as a 'penalty' against the policyholder. However, as has been mentioned, many cases of early termination do not involve any breach of contract on the part of the policyholder and, therefore, there are no grounds for a penalty. Again, the amount of the penalty depends on the time of termination which is merely arbitrary. For all these reasons, any such penalisation of the policyholder must be restricted to extreme cases; see the paragraph below. 
Exceptionally, in case of fraudulent breach of precontractual information duties, the insurer may keep all premiums paid in spite of the retroactive effect of avoidance under Article 2:104. This rule serves as a deterrent to applicants from committing fraud on part of the applicant when carrying out pre-contractual information duties.

\section{Article 5:105. Right to Pay Premium}

The insurer shall not be entitled to refuse payment by a third party if

(a) the third party acts with the assent of the policyholder; or

(b) the third party has a legitimate interest in maintaining the cover and the policyholder has failed to pay or it is clear that he will not pay at the time payment is due.

\section{Comments}

\section{The obligation of the insurer to accept payment}

The policyholder is the person who owes the premium. He is obliged to pay and the insurer must accept his payment. In contrast, third parties - including the insured and beneficiary - do not owe the premium and, therefore, do not have to make any payments. However, third parties sometimes want to pay so that the insurer is not relieved of its obligation to cover the risk. This is usually the case when the third party benefits from cover, for example, either directly as an insured, or indirectly as a pledgee. In other cases, payment by a third party is intended as a gift to the policyholder, for example, when a mother continues to pay health insurance premiums for her bankrupt son. Both cases raise the question of whether an insurer must accept payment from a third party as the payment of the policyholder, even though it seeks to be relieved of its obligation to provide cover in accordance with Article 5:101, 5:102 and to obtain early termination of the contract in accordance with Article 5:103.

Article 5:105 establishes the right of certain third parties to pay the premium on behalf of the policyholder. The wording of the provision is flexible and modelled on the parallel rule contained in Article 7:106 PECL. The wording of Article 7:106 PECL has been adapted to the context of insurance premiums and its contents are made mandatory by virtue of Article 1:103 para. 2 .

\section{Consent of the policyholder}

Payment by a third party must be accepted by the insurer if it is made with the consent of the policyholder (Article 5:105(b)). This will usually be the case when the third party wishes to benefit the policyholder.

\section{Legitimate interest of third party}

Payment by a third party, even where it is made without the consent of the policyholder, must be accepted by the insurer, if the third party has a legitimate interest in 
maintaining the cover (Article 5:105(b)). However, this option is restricted to cases where the policyholder has already failed to pay on time or where it is clear that he is not going to make payment. This restriction is appropriate because, without it, there appears to be no good reason for giving a third party, even one with a legitimate interest, a right to pay premium.

A third party has a legitimate interest in maintaining the cover whenever he benefits from it either directly or indirectly. The insured and the beneficiary under the policy both benefit directly from cover and are thus entitled to pay premium in accordance with Article 5:105(b). Third parties who have an interest in the subject matter of insurance or who would otherwise have to cover losses resulting from an insured event benefit indirectly from cover and are also entitled to effect payment. This is the case, for example, with a relative who would otherwise have to cover losses resulting from an insured event because he may be obliged to provide maintenance for the policyholder. It also applies to pledgees who would lose their security if the property pledged was destroyed after the insurer was released from its obligation to provide cover on account of non-payment of premium. Moreover, a tenant may also have a legitimate interest in effecting payment of premium for insurance taken out on the tenanted property, if he has reason to fear that it could not be rebuilt for lack of funds were it to be destroyed by fire. The cases mentioned are only examples and, thus, do not represent an exhaustive list. 